\title{
Organic Carbon Metabolism and Carbonate Dynamics in a Mediterranean Seagrass (Posidonia oceanica) Meadow
}

\author{
Cristina Barrón ${ }^{1, *}$, Carlos M. Duarte ${ }^{1}$, Michel Frankignoulle ${ }^{2, \dagger}$, and \\ Alberto Vieira Borges ${ }^{2}$ \\ ${ }^{1}$ IMEDEA (CSIC-UIB), Grupo de Oceanografia Interdisciplinar, C/ Miquel Marqués 21, 07190 \\ Esporles (Islas Baleares), Spain \\ ${ }^{2}$ Chemical Oceanography Unit, MARE, University of Liège, Institut de Physique (B5), B-4000 Liège, \\ Belgium
}

\begin{abstract}
We measured monthly dissolved oxygen (DO) changes in situ benthic incubations from March 2001 to October 2002 in a Posidonia oceanica meadow and unvegetated sediments of Magalluf Bay (Mallorca Island, Spain) to determine gross primary production (GPP), community respiration (R), and net community production (NCP). From June 2001 to October 2002, we also measured fluxes of dissolved inorganic carbon (DIC) and total alkalinity (TAlk). The yearly integrated metabolic rates based on DO changes show that the $P$. oceanica communities are net autotrophic while the metabolic rates in the unvegetated benthic communities are nearly balanced. Higher calcium carbonate $\left(\mathrm{CaCO}_{3}\right)$ cycling, both in terms of production and dissolution, was observed in $P$. oceanica communities than in unvegetated benthic communities. In the $P$. oceanica meadow, the annual release of $\mathrm{CO}_{2}$ from net $\mathrm{CaCO}_{3}$ production corresponds to almost half of the $\mathrm{CO}_{2}$ uptake by NCP based on DIC incubations. In unvegetated benthic communities, the annual uptake of $\mathrm{CO}_{2}$ from net $\mathrm{CaCO}_{3}$ dissolution almost fully compensates the $\mathrm{CO}_{2}$ release by NCP based on DIC incubations. $\mathrm{CaCO}_{3}$ dynamics is potentially a major factor in $\mathrm{CO}_{2}$ benthic fluxes in seagrass and carbonate-rich temperate coastal ecosystems.
\end{abstract}

\section{Introduction}

Seagrass meadows are highly productive habitats among coastal ecosystems (Duarte and Chiscano 1999). The interference of seagrass canopies with water flow leads to enhanced particle deposition, retention, and degradation (Agawin and Duarte 2002; Gacia et al. 2002; Duarte et al. 2004). The high production and input of organic carbon make seagrass meadows sites of elevated microbial activity, as well as enhanced animal abundance, which result in high heterotrophic activity (Hemminga and Duarte 2000; Middelburg et al. 2005). In addition to their important metabolic activity, seagrass meadows also support high calcium carbonate $\left(\mathrm{CaCO}_{3}\right)$ production (cf., Canals and Ballesteros 1997; Gattuso et al. 1998; Gacia et al. 2003) and dissolution (Morse et al. 1987; Ku et al. 1999; Burdige and Zimmerman 2002). Seagrass meadows are sites of intense organic and inorganic carbon fluxes. These fluxes are seldom examined in concert so that carbon budget of seagrass meadows, and their potential role as carbon sinks or sources, remains poorly constrained. There is an abundant literature on the organic carbon metabolism of seagrasses (Gattuso et al. 1998; Hemminga and Duarte 2000; Middelburg et al. 2005). Most studies

\footnotetext{
*Corresponding author; tele: 34971 611726; fax: 34971 611761; e-mail: ieacbe@uib.es.

$\dagger$ Deceased March 13, 2005

focused on dissolved oxygen (DO) changes, but this is only a good indicator in the presence of anaerobic respiration when the reduced products are oxidized (Canfield et al. 1993). $\mathrm{CaCO}_{3}$ production and dissolution prevents direct inferences on organic carbon fluxes from dissolved inorganic carbon (DIC) measurements. The examination of the metabolism and carbon fluxes of seagrass meadows requires the joint analysis of organic carbon and $\mathrm{CaCO}_{3}$ fluxes, which to the best of our knowledge, has not yet been studied simultaneously and on an annual scale, using a whole sediment approach (integrating belowground and aboveground compartments).

Posidonia oceanica is an endemic Mediterranean seagrass species with extensive and productive meadows (Duarte and Chiscano 1999; Hemminga and Duarte 2000). P. oceanica meadows are highly productive compared to other seagrass systems (Duarte and Chiscano 1999), and have also been reported to be sites of high DIC fluxes (Frankignoulle and Disteche 1987; Gazeau et al. 2004) and $\mathrm{CaCO}_{3}$ production (Romero 1988; Canals and Ballesteros 1997). P. oceanica meadows support highly active bacterial communities (López et al. 1995) and enhanced sulfate reduction rates relative to unvegetated sediments (Holmer et al. 2003).

We investigated the organic and inorganic carbon metabolism of a $P$. oceanica meadow on the annual scale, providing a comprehensive examination of 
the carbon fluxes. We used changes of DO and DIC in in situ benthic chambers to examine, at monthly intervals, the community metabolism and the net $\mathrm{CaCO}_{3}$ production of a $P$. oceanica meadow relative to adjacent unvegetated sediments located in Mallorca Island (Spain).

\section{Methods}

The study was conducted in a $7 \mathrm{~m}$ deep $P$. oceanica meadow and unvegetated sediments in Magalluf Bay (Mallorca Island, Spain, 39 $30.23^{\prime} \mathrm{N}$, $\left.2^{\circ} 32.60^{\prime} \mathrm{E}\right)$. Sediment was mainly composed of biogenic coarse $(<0.5 \mathrm{~mm})$ to fine $(<0.125 \mathrm{~mm})$ sands with more than $90 \%$ content in $\mathrm{CaCO}_{3}$ (Diaz del Rio et al. 1994). Community metabolism was studied once a month from March 2001 to October 2002. From June 2001 to October 2002, estimations of DIC and total alkalinity (TAlk) fluxes were also conducted. Experimental periods encompassed the diversity of meteorological situations experienced along the year in the study area, except for the strongest storm events, when experiments could not be conducted.

The organic community metabolism and fluxes of DIC and TAlk were studied using in situ benthic chambers deployed by SCUBA divers. Four arbitrarily placed replicated chambers enclosed parcels of the $P$. oceanica meadow and 3 additional chambers were set up in adjacent unvegetated sediments. The in situ benthic chambers consisted of a polyvinyl chloride rigid cylinder $(18 \mathrm{~cm}$ in diameter) firmly inserted, with a sharpened side, about $7-10 \mathrm{~cm}$ into the sediments and a gas-tight polyethylene plastic bag (Hansen et al. 2000) fitted to this cylinder, and a sampling port to withdraw water samples. The walls of the polyethylene plastic bags are flexible structures across which turbulence propagates to the interior of the incubation chamber. Injection of a fluorescent dye (fluorescein) in the experimental chambers showed mixing times to be on the order of $5 \mathrm{~s}$. In order to avoid the possible resuspension of material in the benthic chambers, the sampling of the benthic chambers started after setup of all the chambers. The chambers were deployed in the morning and the enclosed water was sampled using 50-ml (polyethylene) acid-washed syringes just before sunset and right after sunrise. At the end of the experiment $5 \mathrm{ml}$ of a $0.25 \mathrm{~mol} \mathrm{l}^{-1}$ phosphate solution was injected in each chamber and allowed to mix for 5 min before sampling. The water samples were collected and kept frozen until spectrophotometric determination of the phosphate concentration (Hansen and Koroleff 1999). The volume of each incubation chamber was calculated as the difference in phosphate concentration from the solution injected and the water sample collected from the chambers, according to:

$\operatorname{Volume}(\mathrm{ml})=$

$\frac{\text { Volume injected }(\mathrm{ml}) \times \text { concentration injected }\left(\mathrm{mol} \mathrm{l}^{-1}\right)}{(\text { phosphate concentration }) \times \text { dilution factor }}$

where the phosphate concentration of the injected solution was $0.25 \mathrm{~mol}^{-1}$, the volume injected was $5 \mathrm{ml}$, and the dilution of the sample collected to determine the phosphate concentration by the spectrophotometric method.

The volume of water enclosed in the benthic chambers was on average $5 \mathrm{l}$, corresponding to bag dimensions of $58 \mathrm{~cm}$ in perimeter and 45 and $25 \mathrm{~cm}$ tall for $P$. oceanica and unvegetated sediment incubations, respectively. Phosphate has been reported to be removed from the water column within carbonate systems by surface chemisorption (McGlathery et al. 1994), but the possible adsorption of phosphate to the surface was not tested in this study. The $P$. oceanica leaves enclosed in each chamber were harvested at the end of the experiment, rinsed, and dried at $60^{\circ} \mathrm{C}$ to estimate leaf biomass.

Samples for DO concentration were fixed immediately after the end of the dive and were determined by high-precision Winkler titration with a Mettler DL21 titrator (Carritt and Carpenter 1966) and a reproducibility of $0.35 \%$. pH and TAlk were analyzed in samples collected at the start and end of the incubations. $\mathrm{pH}$ was measured in the laboratory within $2 \mathrm{~h}$ of sampling using a combined electrode (ORION 81-02) calibrated on the total hydrogen ion concentration scale $\left(\mathrm{mol} \mathrm{kg} \mathrm{SW}^{-1}\right)$, using the buffers proposed by Dickson (1993). The reproducibility of the $\mathrm{pH}$ measurements is estimated to be $\pm 0.004 \mathrm{pH}$ units. TAlk samples were filtered onto $0.2-\mu \mathrm{m}$ pore size polysulfone filters to avoid biological alteration and stored at room temperature until analysis. TAlk was measured on approximately $50 \mathrm{ml}$ samples by a titration system composed of an ORION 81-02 pH electrode calibrated on the National Bureau of Standards Scale, a METROHM 776 Dosimat titrator, a $50 \mathrm{ml}$ open cell (kept at room temperature), and a FLUKE 51 thermometer. The samples were weighed prior to the titration with a precision and accuracy of $0.01 \mathrm{~g}$, using a METTLER College 1300 scale. The exact volume was then computed from salinity and temperature. The temperature of the water sample was measured at the start of each analysis and used in the $\mathrm{pH}$ calculation and the sample volume computation. The electrode potential was read with a Fluke 45 multimeter interfaced to a personal computer, and the $\mathrm{pH}$ was computed by a custom developed DOS software, at each 0.05-ml increment of $\mathrm{HCl}$ with a concentration of $0.1 \mathrm{~mol} \mathrm{l}^{-1}$. The end point was computed from the Gran function 
applied to the $\mathrm{pH}$ variations from 4.2 to 3.0 , as a function of the added volume of $\mathrm{HCl}$. The TAlk measurements had a reproducibility of $\pm 2 \mu \mathrm{mol} \mathrm{kg}{ }^{-1}$ and an estimated accuracy of $\pm 3 \mu \mathrm{mol} \mathrm{kg} \mathrm{k}^{-1}$. DIC was calculated from $\mathrm{pH}$ and TAlk data and salinity and water temperature measurements from concomitant CTD profiles, and with the dissociation constants of carbonic acid and borate from Roy et al. (1993) with an estimated accuracy of $\pm 5 \mu \mathrm{mol} \mathrm{kg} \mathrm{kg}^{-1}$.

The monthly gross primary production (GPP), community respiration (R), and net community production (NCP) were estimated from DO concentration changes. Hourly rates of R and NCP were estimated from the difference in DO concentrations in the chambers during the night and day, respectively. Hourly rates of GPP were computed as the sum of the hourly rates of $\mathrm{R}$ and NCP. Daily rates of GPP were calculated by multiplying the hourly GPP by the photoperiod. Daily rates of $\mathrm{R}$ were calculated by multiplying the hourly respiration by 24 . Daily rates of NCP were estimated as the difference between daily rates of GPP and R. We acknowledge that time series measurements would have improved the estimate of $\mathrm{R}$ and GPP, but we elected to calculate DO changes over $24 \mathrm{~h}$ intervals, to allocate our efforts to setup of replicate benthic chambers with a fairly high temporal coverage (monthly intervals during $1.5 \mathrm{yr}$ ). The calculations derived from time series are not simple, as the magnitude of GPP changes over time due to changes in light intensity, so that eventually GPP needs be integrated over time, to render results comparable to those derived with the present approach. Metabolic rates in DO units were converted to carbon units assuming photosynthetic and respiratory quotients of 1 , but variability from these quotients may introduce errors in the estimates as discussed in detail by Kirk (1983). Benthic annual metabolism was derived from the sum of the daily metabolic rates measured each month multiplied by the number of days per month.

The factor of DIC involved in organic carbon metabolism (DIC ${ }^{*}$ ) was calculated from DIC and TAlk values according to Broecker and Peng (1982):

$$
\mathrm{DIC}^{*}=\mathrm{DIC}-0.5 \mathrm{TAlk}
$$

The variations of DIC in the incubations potentially integrate both organic carbon metabolism (photosynthesis and organic carbon degradation) and inorganic carbon metabolism $\left(\mathrm{CaCO}_{3}\right.$ precipitation and dissolution). The precipitation of $1 \mathrm{~mol}$ of $\mathrm{CaCO}_{3}$ decreases DIC by $1 \mathrm{~mol}$ and TAlk by 2 mol, according to:

$$
\mathrm{Ca}^{2}+\mathrm{CO}_{3}^{2-} \rightarrow \mathrm{CaCO}_{3}
$$

and, according to the definition of these quantities:

$$
\begin{gathered}
\mathrm{DIC}=\left[\mathrm{CO}_{2}\right]+\left[\mathrm{HCO}_{3}{ }^{-}\right]+\left[\mathrm{CO}_{3}{ }^{2-}\right] \\
\text { TAlk }=\left[\mathrm{HCO}_{3}{ }^{-}\right]+2\left[\mathrm{CO}_{3}{ }^{2-}\right]+\left[\mathrm{B}(\mathrm{OH})_{4}{ }^{-}\right] \\
+[\text {minor ions }]+\left[\mathrm{OH}^{-}\right]-\left[\mathrm{H}^{+}\right]
\end{gathered}
$$

Since borate is conservative in seawater, TAlk variations are mainly a function of $\left[\mathrm{HCO}_{3}{ }^{-}\right]$and $\left[\mathrm{CO}_{3}{ }^{2-}\right]$ changes. A value of -0.5 TAlk corresponds to the number of moles of DIC involved in the precipitation (or dissolution) of $\mathrm{CaCO}_{3}$ (Smith and Key 1975). DIC* corresponds to the fraction of DIC involved in organic carbon metabolism since photosynthesis or aerobic respiration have a negligible effect on TAlk (Broecker and Peng 1982). The flux of DIC associated to organic carbon metabolism (FDIC ${ }^{*}$ ) was computed, assuming that TAlk variations during the incubations are solely related to $\mathrm{CaCO}_{3}$ production or dissolution. Fluxes of DIC (FDIC), DIC* (FDIC $^{*}$ ), and TAlk (FTAlk) based on initial and final values were computed as outline above for DO. Since $\mathrm{pH}$ and TAlk were not sampled at dusk, GPP and R cannot be derived from these quantities, and the comparison with the DO incubations is limited to NCP.

The results derived are affected by several sources of uncertainty, such as the possible horizontal advection across the sediment of gases and metabolic products, a common problem of benthic chamber measurements in permeable sediments (Huettel and Gust 1992).

\section{Statistical AnAlyses}

A Wilcoxon ranked sign test was used to compare metabolic rates (GPP, NCP, and R) and FDIC, FDIC $^{*}$, and FTAlk between the $P$. oceanica system and unvegetated sediment. Least-squares linear regression analysis was used to describe the correlation between the water temperature and GPP and $\mathrm{R}$ of both benthic communities, and the relationship between NCP based on changes of DO and DIC $^{*}$ in the $P$. oceanica system and unvegetated sediment. Least-squares linear regression analysis also was used to describe the correlation between NCP based on DIC and DO to FTAlk. This analysis was also used to examine the relationship between the $P$. oceanica leaf biomass and FTAlk values.

\section{Results}

Water temperature reached a maximum of $27.5^{\circ} \mathrm{C}$ and minimum of $13.9^{\circ} \mathrm{C}$ in August 2001 and January 2002, respectively (Fig. 1). The leaf biomass of $P$. oceanica was highest in spring (April 2001) and summer (August 2002) with $859.0 \pm 146.6 \mathrm{~g} \mathrm{dw} \mathrm{m}^{-2}$ 


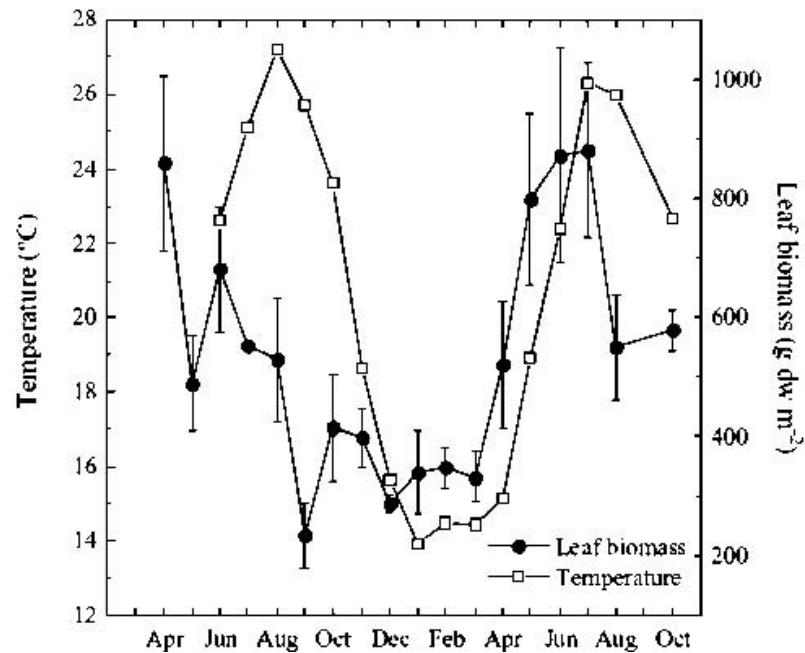

Fig. 1. Water temperature $\left({ }^{\circ} \mathrm{C}\right)$ and Posidonia oceanica leaf biomass $\left(\mathrm{g} \mathrm{dw} \mathrm{m}^{-2} ; \mathrm{n}=4\right)$ during the benthic incubations run in 2001 and 2002. Average \pm SE shown.

and $880.5 \pm 145.6 \mathrm{~g} \mathrm{dw} \mathrm{m}^{-2}$, respectively, and showed minimum values during fall.

GPP in $P$. oceanica vegetated sediments was significantly higher (Wilcoxon, $\mathrm{p}<0.001$ ) on average, 20-fold higher than in unvegetated sediments (Fig. 2), ranging from $24.7 \pm 5.3$ to $173.3 \pm$ $13.4 \mathrm{mmol} \mathrm{C} \mathrm{m}^{-2} \mathrm{~d}^{-1}$, with maximum values in spring and summer and lowest values in fall and winter. GPP in unvegetated sediments ranged from $0.6 \pm 0.1$ to $8.9 \pm 3.4 \mathrm{mmol} \mathrm{C} \mathrm{m}^{-2} \mathrm{~d}^{-1}$, with a similar seasonal trend as for the P. oceanica community. $\mathrm{R}$ in unvegetated benthic communities ranged from 1.8 \pm 0.3 to $10.6 \pm 0.1 \mathrm{mmol} \mathrm{C} \mathrm{m}{ }^{-2} \mathrm{~d}^{-1}$, and was, on average, 15-fold lower than that in the $P$. oceanica vegetated sediment (Wilcoxon, $\mathrm{p}<0.001$ ), which ranged from $18.0 \pm 2.6$ in January 2002 to $141.9 \pm$ $22.9 \mathrm{mmol} \mathrm{C} \mathrm{m} \mathrm{C}^{-2} \mathrm{~d}^{-1}$ in August 2001. GPP was independent of water temperature for both seagrass and unvegetated benthic communities $(\mathrm{p}>0.05)$. For the P. oceanica community, GPP was independent of leaf biomass $(p>0.05)$. $R$ was significantly correlated to water temperature $\left(\mathrm{r}^{2}=0.29, \mathrm{p}<\right.$ $0.05)$ in $P$. oceanica, but not in unvegetated benthic communities. The $P$. oceanica community tended to be net autotrophic and unvegetated benthic communities tended to be net heterotrophic. NCP of the meadow ranged from $-24.7 \pm 7.0$ to $88.8 \pm$ $6.4 \mathrm{mmol} \mathrm{C} \mathrm{m}^{-2} \mathrm{~d}^{-1}$ in August 2002 and April 2002, respectively. NCP in unvegetated sediments was much lower than in the $P$. oceanica meadow, being net autotrophic during summer and fall 2001 and remaining net heterotrophic during the other periods. The NCP in P. oceanica system significantly exceeded (Wilcoxon, $p<0.05$ ) that in the unvegetated sediment. GPP and R were significantly
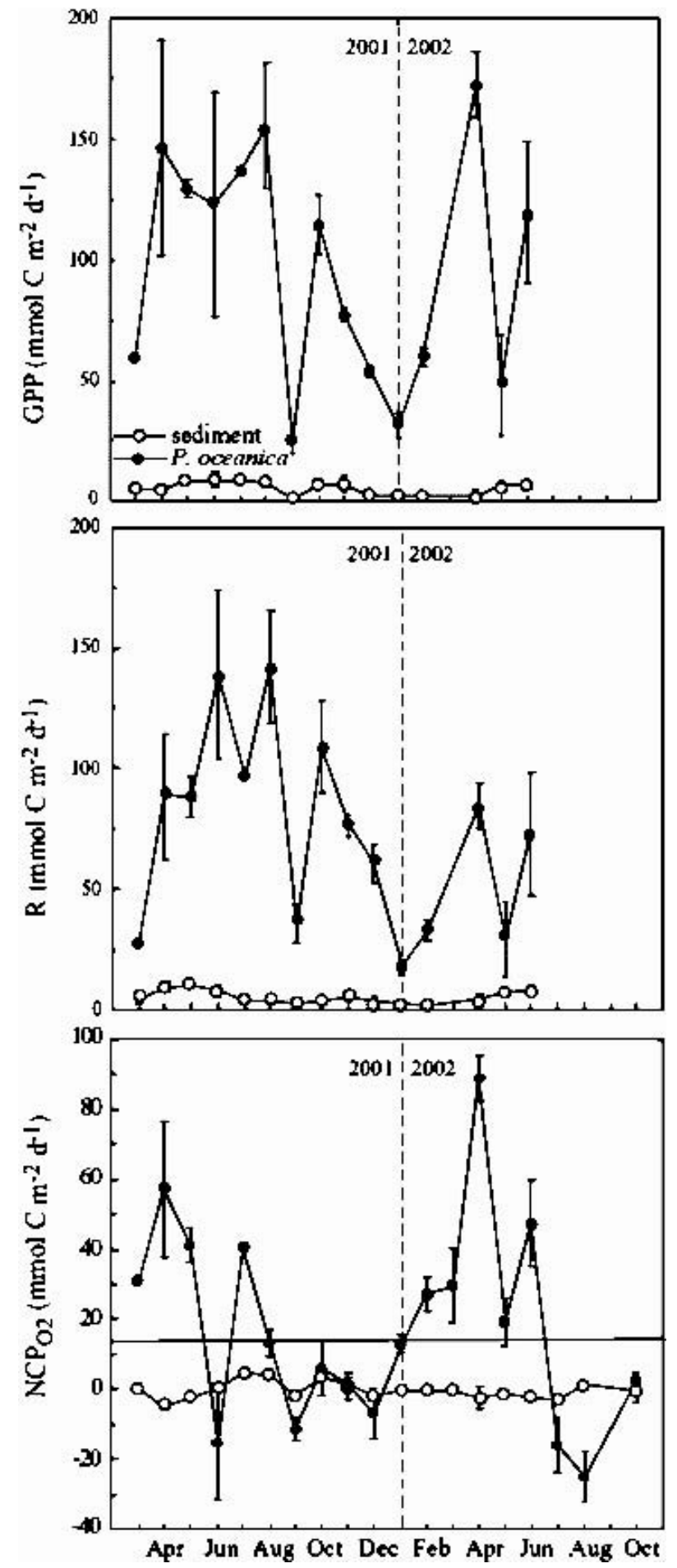

Fig. 2. Gross primary production (GPP), community respiration (R), and net community production (NCP) in mmol $\mathrm{C}$ $\mathrm{m}^{-2} \mathrm{~d}^{-1}$ in the $P$. oceanica meadow $(\mathrm{n}=4)$ and the adjacent unvegetated benthic communities $(\mathrm{n}=3)$ along the studies conducted during 2001 and 2002 using the DO method. Average \pm SE shown. 


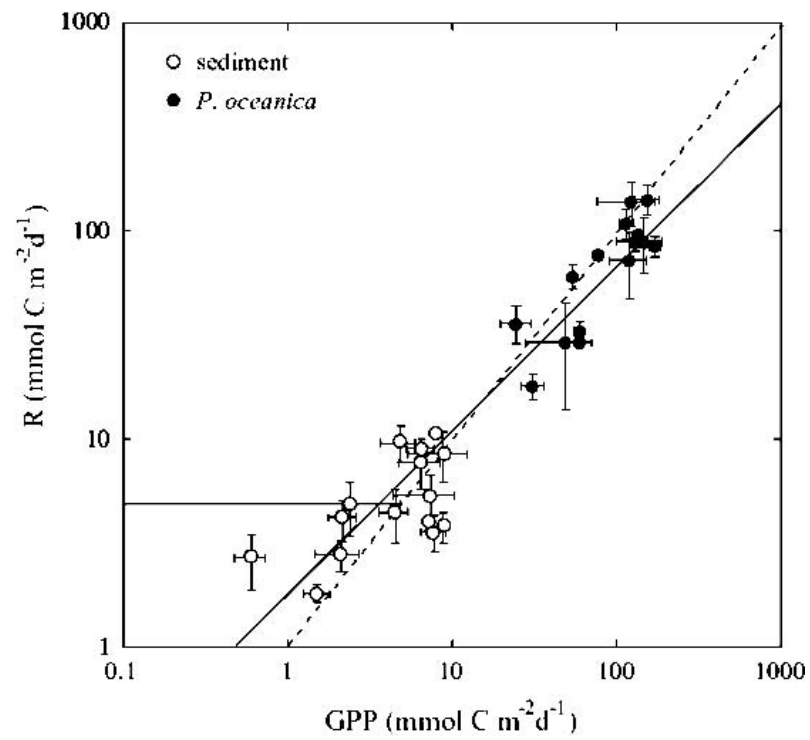

Fig. 3. Relationship between the gross primary production (GPP) and the community respiration (R) in mmol $\mathrm{C} \mathrm{m}^{-2} \mathrm{~d}^{-1}$ in the unvegetated $(n=3)$ and vegetated $(n=4)$ benthic communities (solid line). Dashed line represents the 1:1 line. Average \pm SE shown.

correlated $\left(\mathrm{r}^{2}=0.87, \mathrm{p}<0.001\right)$ in both benthic communities (Fig. 3).

The intensity and amplitude of seasonal variations of FDIC, FDIC*, and FTAlk were much higher in $P$. oceanica communities than in unvegetated sediments, but mean values were not significantly higher (Wilcoxon, $\mathrm{p}<0.05$; Fig. 4). No clear seasonality of FTAlk was observed in unvegetated sediments, unlike $P$. oceanica vegetated sediments. In $P$. oceanica communities, FDIC* was always lower than FDIC, with values on average 0.85 times lower. The only exception was for P. oceanica in July 2002, when a very high FTAlk value induced a large correction, with FDIC and FDIC $^{*}$ values of 7 and $-21 \mathrm{mmol} \mathrm{C} \mathrm{m}^{-2} \mathrm{~d}^{-1}$, respectively. In unvegetated benthic communities, FDIC ${ }^{*}$ was either lower or higher than FDIC, but on average FDIC* was 0.84 times lower than FDIC. In unvegetated benthic communities, a very high FTAlk value was also observed in July 2002, with FDIC and FDIC* values of 4 and $-1 \mathrm{mmol} \mathrm{C} \mathrm{m}^{-2} \mathrm{~d}^{-1}$, respectively. In unvegetated sediments, unlike $P$. oceanica communities, no clear seasonality of FDIC and FDIC * was observed.

NCP estimates based on DIC* $\left(\mathrm{NCP}_{\text {DIC* }}\right)$ followed closely the temporal trends of the NCP estimates based on $\mathrm{DO}\left(\mathrm{NCP}_{\mathrm{O} 2}\right.$; Fig. 5). $\mathrm{NCP}_{\mathrm{O} 2}$ was significantly correlated to $\mathrm{NCP}_{\mathrm{DIC}^{*}}$ in $P$. oceanica $\left(\mathrm{r}^{2}=\right.$ $0.61, \mathrm{p}<0.001)$; in unvegetated sediment there was a weak correlation $\left(\mathrm{r}^{2}=0.36, \mathrm{p}<0.001\right)$. In $P$. oceanica communities, $\mathrm{NCP}_{\mathrm{DIC}^{*}}$ estimates were sys-
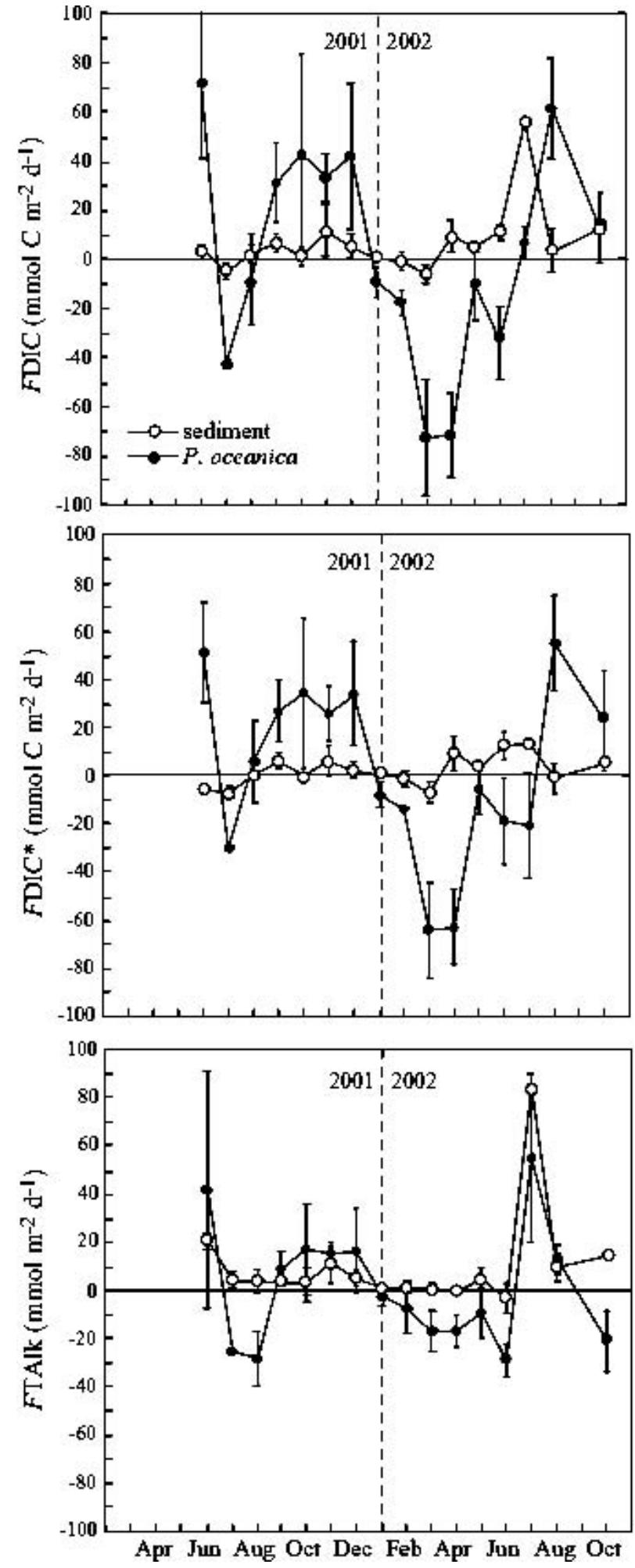

Fig. 4. Evolution of FDIC $\left(\mathrm{mmol} \mathrm{C} \mathrm{m}^{-2} \mathrm{~d}^{-1}\right)$, FDIC ${ }^{*}(\mathrm{mmol} \mathrm{C}$ $\left.\mathrm{m}^{-2} \mathrm{~d}^{-1}\right)$, and FTAlk $\left(\mathrm{mmol} \mathrm{m}^{-2} \mathrm{~d}^{-1}\right)$ in $P$. oceanica vegetated $(\mathrm{n}$ $=4$, filled circles) and unvegetated $(\mathrm{n}=3$, open circles) sediments. Error bars indicate SE. 


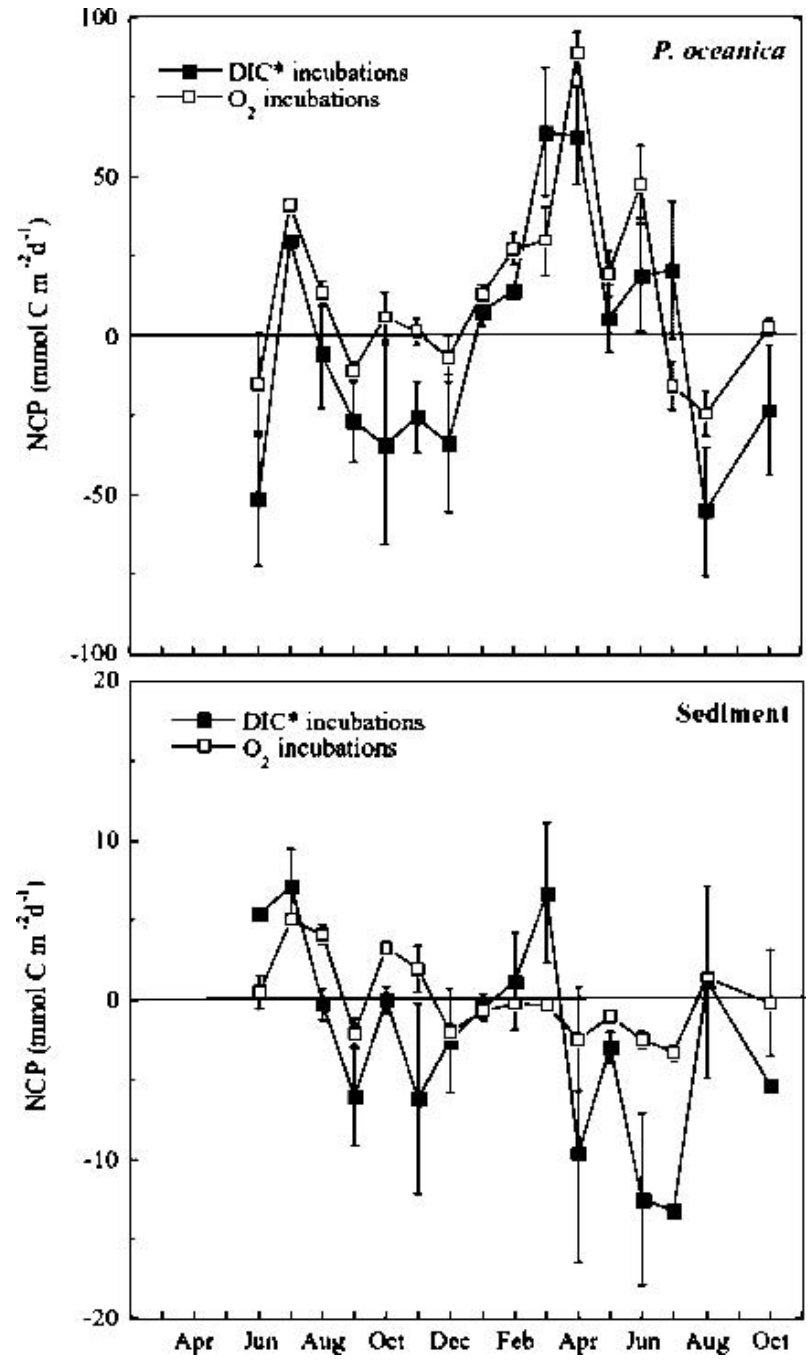

Fig. 5. Evolution NCP based on DIC $\left(\mathrm{mmol} \mathrm{C} \mathrm{m}{ }^{-2} \mathrm{~d}^{-1}\right.$, filled squares) and $\mathrm{O}_{2}$ incubations (mmol $\mathrm{C} \mathrm{m}^{-2} \mathrm{~d}^{-1}$, open squares), in $P$. oceanica meadow $(\mathrm{n}=4)$ and unvegetated benthic communities $(\mathrm{n}=3)$. $\mathrm{NCP}_{\mathrm{DIC}^{*}}=-\mathrm{F}_{\mathrm{DIC}}$. Error bars indicate SE.

tematically lower than $\mathrm{NCP}_{\mathrm{O} 2}$ estimates (except for incubations in February and July 2002). When $\mathrm{NCP}_{\mathrm{O} 2}$ values were close to zero or slightly negative,

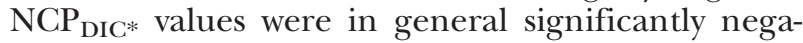
tive in both $P$. oceanica vegetated and unvegetated benthic communities.

In $P$. oceanica communities, FTAlk values were significantly correlated to $\mathrm{NCP}_{\mathrm{O} 2}(\mathrm{p}<0.001)$ and $\mathrm{NCP}_{\text {DIC*}^{*}}$ estimates $(\mathrm{p}<0.01$; Fig. 6$)$. Positive FTAlk values were observed when the system was net heterotrophic, while negative FTAlk values were observed when the system was net autotrophic. The positive and negative FTAlk values, when treated separately, were apparently related to the $P$. oceanica leaf biomass; positive FTAlk values were significantly correlated $(\mathrm{p}<0.05)$ with leaf biomass, and negative values were not significantly correlated ( $\mathrm{p}$ $>0.05)$ with the biomass. In unvegetated benthic communities, no correlation was found between FTAlk and either NCP or water temperature (not shown).

\section{Discussion}

The estimation of NCP from DIC values computed from TAlk and $\mathrm{pH}$ relies on the assumption that TAlk variations during the incubations are solely related to $\mathrm{CaCO}_{3}$ precipitation or dissolution. The buildup of $\mathrm{CO}_{2}$ from the aerobic respiration in the oxic sediment layers can lead to $\mathrm{CaCO}_{3}$ undersaturation and dissolution. Holmer et al. (2003) reported that sulfate reduction is the dominant anaerobic degradation pathway in sediments around the Mallorca Island, Spain. Sulfide oxidation in the suboxic and oxic sediment layers can drive $\mathrm{CaCO}_{3}$ dissolution due to the buildup of protons from the oxidation of $\mathrm{H}_{2} \mathrm{~S}$ (e.g., $\mathrm{Ku}$ et al. 1999; Ogrinc et al. 2003). A simple stoichiometry of sulfate reduction is given by:

$$
2 \mathrm{CH}_{2} \mathrm{O}+\mathrm{SO}_{4}{ }^{2-} \rightarrow \mathrm{H}_{2} \mathrm{~S}+2 \mathrm{HCO}_{3}{ }^{2-}
$$

The oxidation of $\mathrm{H}_{2} \mathrm{~S}$ produces protons according to:

$$
\mathrm{H}_{2} \mathrm{~S}+2 \mathrm{O}_{2} \rightarrow \mathrm{SO}_{4}{ }^{2-}+2 \mathrm{H}
$$

The buildup of protons in the suboxic and oxic sediment layers can lead to $\mathrm{CaCO}_{3}$ undersaturation and $\mathrm{CaCO}_{3}$ dissolution, according to:

$$
\mathrm{CaCO}_{3}+2 \mathrm{H}^{+} \rightarrow 2 \mathrm{Ca}^{2+}+2 \mathrm{HCO}_{3}{ }^{2-}
$$

The net reaction is given by the sum of Eqs. 6, 7, and 8 :

$$
\mathrm{CaCO}_{3}+\mathrm{O}_{2}+\mathrm{CH}_{2} \mathrm{O} \rightarrow \mathrm{Ca}^{2+}+2 \mathrm{HCO}_{3}-
$$

The other process that can lead to $\mathrm{CaCO}_{3}$ dissolution in sediments is aerobic respiration that produces $\mathrm{CO}_{2}$ according to the stoichiometry:

$$
\mathrm{CH}_{2} \mathrm{O}+\mathrm{O}_{2} \rightarrow \mathrm{H}_{2} \mathrm{O}+\mathrm{CO}_{2}
$$

The buildup of $\mathrm{CO}_{2}$ in oxic sediment layers can lead to $\mathrm{CaCO}_{3}$ undersaturation and $\mathrm{CaCO}_{3}$ dissolution, according to:

$$
\mathrm{CaCO}_{3}+\mathrm{CO}_{2}+\mathrm{H}_{2} \mathrm{O} \rightarrow \mathrm{Ca}^{2+}+2 \mathrm{HCO}_{3}^{-}
$$

The net reaction is given by the sum of Eqs. 10 and 11 and is identical to Eq. 9. This means that it is not possible to discriminate from DIC, TAlk, and $\mathrm{Ca}^{2+}$ stoichiometries, if $\mathrm{CaCO}_{3}$ dissolution is derived from aerobic organic carbon degradation or from $\mathrm{CaCO}_{3}$ dissolution derived from the oxidation of $\mathrm{H}_{2} \mathrm{~S}$ produced by sulfate reduction. 

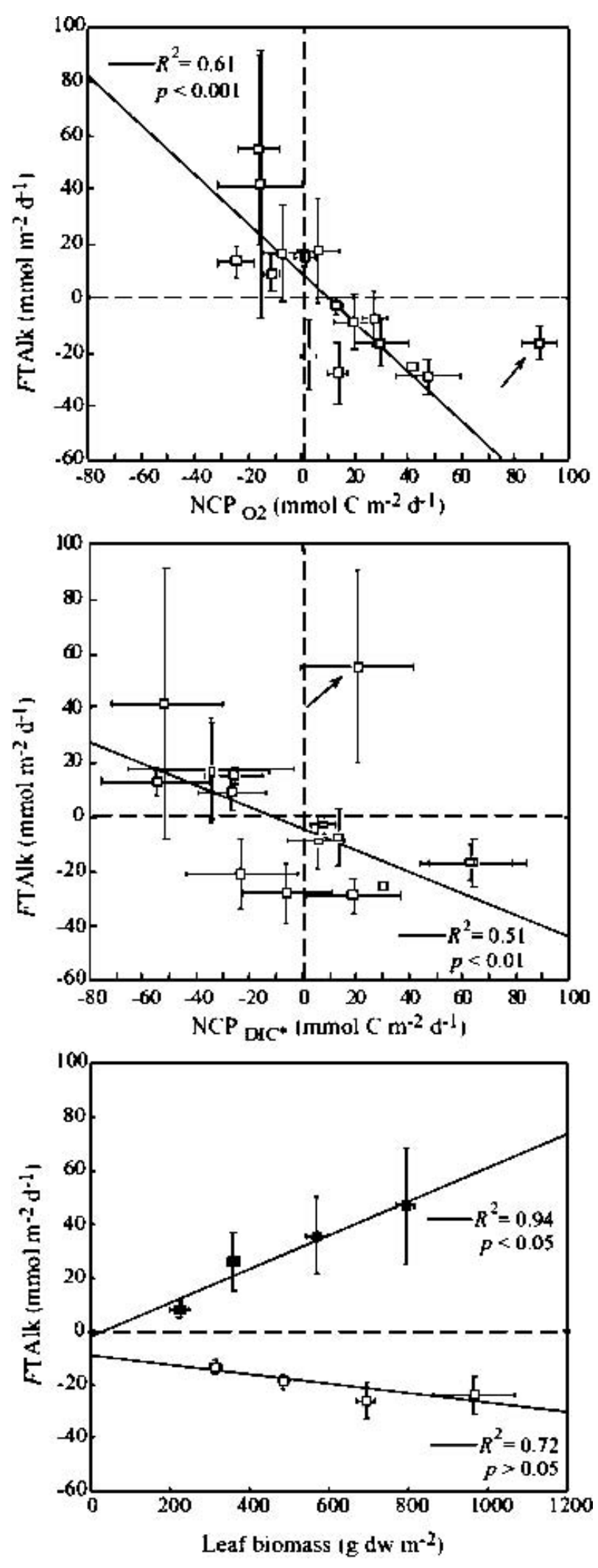

Much higher $\mathrm{CaCO}_{3}$ cycling both in terms of production and dissolution was observed in $P$. oceanica meadows compared to unvegetated sediments. Enhanced $\mathrm{CaCO}_{3}$ dissolution in seagrass vegetated sediments compared to adjacent unvegetated sediments has been documented in Thalassia testudium meadows of the Bahamas (Morse et al. 1987; Burdige and Zimmerman 2002) and in mixed meadows of Florida Bay ( $\mathrm{Ku}$ et al. 1999; Yates and Halley 2003, 2006). The enhanced $\mathrm{CaCO}_{3}$ dissolution in seagrass meadows is attributed to intensified sediment metabolic activity related to higher organic carbon availability, $\mathrm{O}_{2}$ diffusion from rhizomes to pore waters (Ku et al. 1999; Burdige and Zimmerman 2002), or sulfate reduction (Ku et al. 1999; Yates and Halley 2006). The first two processes are assumed to be positively related to aboveground seagrass production (Burdige and Zimmerman 2002), while the last is negatively related to shoot density and root biomass (Holmer et al. 2003). Although $\mathrm{O}_{2}$ diffusion from rhizomes to pore waters has not been demonstrated in $P$. oceanica, it was invoked by Holmer et al. (2003) to explain the spatial variations of sulfate reduction rates within $P$. oceanica meadows around Mallorca Island.

Particulate organic carbon (POC) and nitrogen (PON) content and total phosphorus content (TP) in Magalluf Bay in autumn 2000 and May and June 2001 are reported in Holmer et al. (2003, 2004). Bare sediments in Magalluf Bay had lower POC and PON content $(0.19 \%$ and $0.21 \%$ POC; $0.017 \%$ and $0.030 \%$ PON) compared to $P$. oceanica meadows $(0.26 \%$ and $0.38 \%$ POC; $0.031 \%$ and $0.041 \%$ PON; Holmer et al. 2003, 2004). TP content in P. oceanica and unvegetated sediments in Magaluf Bay was 2.9 and $2.4 \mu \mathrm{mol} \mathrm{C} \mathrm{g}^{-1} \mathrm{dw}$, respectively (Holmer et al. 2003). Sulfate reduction is significantly higher in $P$. oceanica sediments than in bare sediments in Magalluf, and total reducible sulfur concentrations in $P$. oceanica sediments are slightly higher than in bare sediments (Holmer et al. 2004). Pore water sulfides concentrations of both communities in Magalluf Bay are not reported by Holmer et al. (2003), but in three of the sites of Mallorca Island from this study, higher sulfide concentrations were found in sediments under $P$. oceanica than in

$\leftarrow$

Fig. 6. FTAlk $\left(\mathrm{mmol} \mathrm{m}^{-2} \mathrm{~d}^{-1}\right)$ in $P$. oceanica vegetated sediments $(\mathrm{n}=4)$ as function of $\mathrm{NCP}_{\mathrm{O} 2}\left(\operatorname{mmol~C~m} \mathrm{m}^{-2} \mathrm{~d}^{-1}\right)$, $\mathrm{NCP}_{\text {DIC** }}\left(\mathrm{mmol} \mathrm{C} \mathrm{m} \mathrm{m}^{-2} \mathrm{~d}^{-1}\right)$, and total $P$. oceanica leaf biomass $\left(\mathrm{g} \mathrm{dw} \mathrm{m}^{-2}\right)$. Data points indicated with an arrow were excluded from the linear regression represented by solid lines. In the lower panel, the positive and negative FTAlk values were separately bin averaged over leaf biomass bins of $200 \mathrm{~g} \mathrm{dw} \mathrm{m}^{-2}(\mathrm{n}=48)$. A negative FTAlk corresponds to net $\mathrm{CaCO}_{3}$ production and positive FTAlk corresponds to net $\mathrm{CaCO}_{3}$ dissolution. Error bars indicate SE. 
TABLE 1. Annual mean $( \pm \mathrm{SE})$ of gross primary production $\left(\mathrm{GPP}_{\mathrm{O} 2}\right)$, community respiration $\left(\mathrm{R}_{\mathrm{O} 2}\right)$, and net community production $\left(\mathrm{NCP}_{\mathrm{O} 2}\right)$ using $\mathrm{DO}$ incubations, and organic and inorganic metabolic rates based on DIC incubations in a Posidonia oceanica meadow and unvegetated sediments. $\mathrm{NCP}_{\mathrm{DIC}^{*}}=-\mathrm{FDIC}^{*}$; $\mathrm{CaCO}_{3}$ production $=-0.5 \mathrm{FTAlk}$; the molar ratio of $\mathrm{CO}_{2}$ release : $\mathrm{CaCO}_{3}$ production was computed as described by Frankignoulle et al. (1994). Positive net $\mathrm{CO}_{2}$ flux corresponds to a release of $\mathrm{CO}_{2}$ to the overlying water column, and a negative net $\mathrm{CO}_{2}$ flux corresponds to an uptake of $\mathrm{CO}_{2}$ from the overlying water column. All data are expressed in $\mathrm{mol} \mathrm{C} \mathrm{m}{ }^{-2} \mathrm{yr}^{-1}$.

\begin{tabular}{|c|c|c|}
\hline & P. oceanica & Sediment \\
\hline $\mathrm{GPP}_{\mathrm{O} 2}$ & $33.8(5.6)$ & $1.9(0.4)$ \\
\hline $\mathrm{R}_{\mathrm{O} 2}$ & $27.9(5.0)$ & $1.9(0.3)$ \\
\hline $\mathrm{NCP}_{\mathrm{O} 2}$ & $6(2.7)$ & $0.1(0.2)$ \\
\hline $\mathrm{NCP}_{\text {DIC* }}$ & $0.7(3.7)$ & $-0.6(0.6)$ \\
\hline $\mathrm{CaCO}_{3}$ production & $0.5(1.1)$ & $-0.8(0.3)$ \\
\hline $\mathrm{CO}_{2}$ flux from NCP & $-0.7(3.7)$ & $0.6(0.6)$ \\
\hline $\mathrm{CO}_{2}$ flux from $\mathrm{CaCO}_{3}$ production & $0.3(0.7)$ & $-0.5(0.2)$ \\
\hline Net $\mathrm{CO}_{2}$ flux & $-0.4(3.2)$ & $0.1(0.7)$ \\
\hline
\end{tabular}

unvegetated sediments. Oxygen release from $P$. oceanica roots has not been studied but has been reported in other seagrass. For these reasons it might be expected that sulfide oxidation and concomitant pore water acidification in $P$. oceanica sediments would be higher than in unvegetated sediments.

Enhanced $\mathrm{CaCO}_{3}$ dissolution in the pore waters of the $P$. oceanica vegetated sediments in relation to sediment metabolic activity is consistent with the positive FTAlk values observed during net heterotrophic periods (Fig. 6). These processes during heterotrophic periods are related to the aboveground biomass as shown by the positive relationship between FTAlk and leaf biomass. During net autotrophic periods, $\mathrm{CaCO}_{3}$ precipitation overwhelms the sediment $\mathrm{CaCO}_{3}$ dissolution and negative FTAlk values are observed in $P$. oceanica communities. The good relationships between FTAlk and NCP and between FTAlk and leaf biomass can be explained by the fact that growth of epiphyte flora and fauna of $P$. oceanica, among which are calcifying organisms, are mainly related to substrate leaf availability. Epiphyte biomass generally increases from winter to summer following $P$. oceanica leaf biomass turnover (Lepoint et al. 1999). The positive relationship between $\mathrm{CaCO}_{3}$ production and NCP could also in part be related to the contribution of the calcifying epiphyte flora to total NCP. No relation between GPP and P. oceanica leaf biomass occurred as epiphyte carbon assimilation has been estimated to range between $30 \%$ and $50 \%$ of the total $P$. oceanica shoot production (Modigh et al. 1998; Hemminga and Duarte 2000).

On an annual basis (Table 1), a net $\mathrm{CaCO}_{3}$ production of $0.5 \mathrm{~mol} \mathrm{C} \mathrm{m}{ }^{-2} \mathrm{yr}^{-1}\left(51.4 \mathrm{~g} \mathrm{CaCO}_{3}\right.$ $\mathrm{m}^{-2} \mathrm{yr}^{-1}$ ) is estimated in $P$. oceanica vegetated sediments and a net $\mathrm{CaCO}_{3}$ dissolution of $0.8 \mathrm{~mol}$
$\mathrm{C} \mathrm{m}^{-2} \mathrm{yr}^{-1}$ in the unvegetated sediments $(75.8 \mathrm{~g}$ $\left.\mathrm{CaCO}_{3} \mathrm{~m}^{-2} \mathrm{yr}^{-1}\right)$. Our estimate of net $\mathrm{CaCO}_{3}$ production in $P$. oceanica vegetated sediments is in fair agreement with the epiphyte calcification estimate by Canals and Ballesteros (1997) over $P$. oceanica meadows of the Mallorca-Menorca shelf $\left(0.7 \mathrm{~mol} \mathrm{C} \mathrm{m}^{-2} \mathrm{yr}^{-1}, 68.2 \mathrm{~g} \mathrm{CaCO}_{3} \mathrm{~m}^{-2} \mathrm{yr}^{-1}\right)$. Canals and Ballesteros (1997) reported a net annual $\mathrm{CaCO}_{3}$ production for bare sediments of the Mallorca-Menorca shelf of $0.005 \mathrm{~mol} \mathrm{C} \mathrm{m} \mathrm{m}^{-2} \mathrm{yr}^{-1}$ $\left(0.5 \mathrm{~g} \mathrm{CaCO}_{3} \mathrm{~m}^{-2} \mathrm{yr}^{-1}\right)$. This discrepancy is related to the different approaches used, since our approach gives a whole sediment $\mathrm{CaCO}_{3}$ budget, including both benthic production and underlying sediment dissolution, while the approach of Canals and Ballesteros (1997) only yields the benthic production term (based on experimentally determined organisms density and literature yearly production : biomass ratios). This could also explain our somewhat lower estimate of net $\mathrm{CaCO}_{3}$ annual production rate in the $P$. oceanica community, although we cannot exclude other sources of variability, such as spatial heterogeneity and depth variations of $\mathrm{CaCO}_{3}$ production rates.

According to Eq. 11, the precipitation of $\mathrm{CaCO}_{3}$ leads to an increase in the surrounding waters of $\mathrm{CO}_{2}$ transferred from the $\mathrm{HCO}_{3}{ }^{-}$pool. The dissolution of $\mathrm{CaCO}_{3}$ leads to the decrease in the surrounding waters of $\mathrm{CO}_{2}$ transferred to the $\mathrm{HCO}_{3}{ }^{-}$pool. These processes combined with NCP to control the release or uptake of $\mathrm{CO}_{2}$ by a given ecosystem to or from the surrounding water, and determine to a large extent the status of the ecosystem as a source or sink of atmospheric $\mathrm{CO}_{2}$ (e.g., Gattuso et al. 1993, 1998; Frankignoulle et al. 1994; Borges 2005). The net $\mathrm{CaCO}_{3}$ production in $P$. oceanica meadows induces a release of $\mathrm{CO}_{2}$ of about $46 \%$ of $\mathrm{CO}_{2}$ fixed by NCP to the surrounding waters based on the DIC approach (Table 1). The net $\mathrm{CaCO}_{3}$ dissolution in the unvegetated sediments leads to a decrease of $\mathrm{CO}_{2}$ at a yearly rate that corresponds to $84 \%$ of the $\mathrm{CO}_{2}$ released by organic carbon consumption. This clearly illustrates the potential significance of $\mathrm{CaCO}_{3}$ dynamics as a major factor in $\mathrm{CO}_{2}$ fluxes in seagrass and carbonate-rich temperate coastal ecosystems. The net annual rate of $\mathrm{CaCO}_{3}$ production found during this study is at the lower end of the values reported for $P$. oceanica (82-158 $\mathrm{g} \mathrm{CaCO}_{3} \mathrm{~m}^{-2} \mathrm{yr}^{-1}$ off the Catalan coast; Romero 1988) and other seagrass meadows (30$2,800 \mathrm{~g} \mathrm{CaCO}_{3} \mathrm{~m}^{-2} \mathrm{yr}^{-1}$ for various seagrasses; Nelsen and Ginsburg 1986; Frankovich and Zieman 1994).

\section{Conclusions}

The analysis of DO fluxes depicted the studied $P$. oceanica meadow as a net autotrophic community at 
the annual time scale, with a NCP of $6.0 \pm 2.7$ mol $\mathrm{C} \mathrm{m}^{-2} \mathrm{yr}^{-1}$ (Table 1), while the adjacent unvegetated sediments is nearly balanced $(0.1 \pm 0.2 \mathrm{~mol} \mathrm{C}$ $\left.\mathrm{m}^{-2} \mathrm{yr}^{-1}\right)$. These findings are in agreement with the statement, from comparative analyses of daily metabolism in seagrass meadows, that seagrass meadows tend to be net autotrophic (Gattuso et al. 1998; Hemminga and Duarte 2000). Our analysis of DIC changes suggests that $P$. oceanica communities are only slightly net autotrophic while unvegetated sediments are slightly net heterotrophic. The $\mathrm{NCP}_{\text {DIC* }}: \mathrm{NCP}_{\mathrm{O} 2}$ ratios range from 0.8 to 5.0 for unvegetated sediments (average 2.8) and from 0.3 to 4.8 for $P$. oceanica vegetated sediments (average 1.5). Such large discrepancies of NCP estimates based on DIC and DO incubations have already been reported for seagrass meadows; ratios of metabolic rates based on DIC and $\mathrm{O}_{2}$ in T. testudium meadows of Laguna Madre (Texas), range from 0.6 to 6.8 (Ziegler and Benner 1998). In absence of ancillary data, such as $\mathrm{H}_{2} \mathrm{~S}$ burial rates and $\mathrm{Ca}^{2+}$ fluxes, we cannot identify the origin of these discrepancies from the present data set.

A nearly balanced NCP at an annual scale as suggested by the DIC incubations would imply that little excess organic carbon is available for export to adjacent coastal environments or for accumulation as extra aboveground or belowground biomass. $P$. oceanica meadows are known to have high storage rates of organic carbon (e.g., Mateo et al. 1997; Gacia et al. 2002) and to export large amounts of litter (Mateo et al. 2003). At Fanals point (northeast Spain), Gacia et al. (2002) reported that $29 \%$ of the annual deposition of carbon was derived from $P$. oceanica detritus and represents about half of the $P$. oceanica meadow production; in our case that would be about $3 \mathrm{~mol} \mathrm{C} \mathrm{m}^{-2} \mathrm{yr}^{-1}$. The excess mineralization in $P$. oceanica meadows would be supported by the degradation of sestonic organic carbon particles trapped by the meadow (Agawin and Duarte 2002; Gacia et al. 2002), reconciling a low NCP estimate with high accumulation and detritus export of organic carbon produced by $P$. oceanica. Analyses of carbon budgets in seagrass meadows must consider these to be open systems, sustaining significant exchanges (inputs and outputs) with the adjacent pelagic environment.

\section{ACKNOWLEDGMENTS}

We thank everyone involved in $1.5 \mathrm{yr}$ of sampling, and $\mathrm{P}$. Togeskov (Danisco Flexible, Denmark) for providing the plastic film used for the benthic chambers. A. V. Borges is grateful to Gilles Lepoint and Frédéric Gazeau for fruitful discussions. This work was funded by the European Commission (EUROTROPH project, contract number EVK3-CT-2000-00040). C. Barrón is funded by a scholarship from the government of the Balearic Islands. A. V. Borges is a research associate at the Fonds National de la Recherche Scientifique.

\section{Literature Cited}

Agawin, N. S. R. And C. M. Duarte. 2002. Evidence of direct particle trapping by a tropical seagrass meadow. Estuaries 25: 1205-1209.

Borges, A. V. 2005. Do we have enough pieces of the jigsaw to integrate $\mathrm{CO}_{2}$ fluxes in the coastal ocean? Estuaries 28:3-27.

Broecker, W. S. and T.-H. Peng. 1982. Tracers in the Sea, 1st edition. Eldigio Press, New York.

Burdige, D. J. And R. C. Zimmerman. 2002. Impact of seagrass density on carbonate dissolution in Bahamian sediments. Limnology and Oceanography 47:1751-1763.

Canals, M. AND E. Ballesteros. 1997. Production of carbonate particles by phytobenthic communities on the MallorcaMenorca shelf, northwestern Mediterranean Sea. Deep Sea Research II 44:611-629.

Canfield, D. E., B. B. Jørgensen, H. Fossing, R. Glud, J. Gundersen, N. B. Rassing, B. Thamdrup, J. W. Hansen, L. P. Nielsen, and P. O. J. Hall. 1993. Pathways of organic carbon oxidation in three continental margin sediments. Marine Geology 113:27-40.

Carritt, D. E. And J. H. Carpenter. 1966. Comparison and evaluation of currently employed modifications of the Winkler method for determining dissolved oxygen in seawater; a NASCO report. Journal of Marine Research 24:286-319.

Diaz del Rio, V., L. Somoza, J. L. Goy, C. Zazo, J. Rey, F. J. Hernandez-Molina, And G. Mateu. 1994. Mapa Fisiográfico de la Bahía de Palma. Publicaciones Especiales del Instituto Español de Oceanografía 16:39.

Dickson, A. G. 1993. pH buffers for sea water media based on the total hydrogen ion concentration scale. Deep-Sea Research I 40: 107-118.

Duarte, C. M. And C. L. Chiscano. 1999. Seagrass biomass and production: A reassessment. Aquatic Botany 1334:1-16.

Duarte, C. M., J. J. Middelburg, ANd N. Caraco. 2004. Major role of marine vegetation on the oceanic carbon cycle. Biogeosciences Discussions 1:659-679.

Frankignoulle, M., C. Canon, and J.-P. Gattuso. 1994. Marine calcification as a source of carbon dioxide: Positive feedback to increasing atmospheric $\mathrm{CO}_{2}$. Limnology and Oceanography 39: $458-462$.

Frankignoulle, M. And A. Disteche. 1987. Study of the transmission of the diurnal $\mathrm{CO}_{2}$ concentration changes observed above a Posidonia seagrass bed: A method to determine the turbulent diffusion coefficient in an 8-m water column. Continental Shelf Research 7:67-76.

Frankovich, T. A. And J. C. Zieman. 1994. Total epiphyte and epiphytic carbonate production on Thalassia testudium across Florida Bay. Bulletin of Marine Science 54:679-695.

Gacia, E., C. M. Duarte, N. Marbà, J. Terrados, H. Kennedy, M. Fortes, AND N. H. TRI. 2003. Sediment deposition and production in SE-Asia seagrass meadows. Estuarine Coastal and Shelf Science 56:909-919.

Gacia, E., C. M. Duarte, And J. J. Middelburg. 2002. Carbon and nutrient deposition in a Mediterranean seagrass (Posidonia oceanica) meadow. Limnology and Oceanography 47:23-32.

Gattuso, J.-P., M. Frankignoulle, and R. Wollast. 1998. Carbon and carbonate metabolism in coastal aquatic ecosystems. Annual Review of Ecology and Systematics 29:405-434.

Gattuso, J.-P., M. Pichon, B. Delesalle, and M. Frankignoulle. 1993. Community metabolism and air-sea $\mathrm{CO}_{2}$ fluxes in a coral reef ecosystem (Moorea, French Polynesia). Marine Ecology Progress Series 96:259-267.

Gazeau, F., C. M. Duarte, J.-P. Gattuso, C. Barrón, N. Navarro, S. Ruíz, Y. T. Prairie, M. Calleja, B. Delille, M. FranKIgNOUlle, AND A. V. Borges. 2004. Whole-system metabolism and $\mathrm{CO}_{2}$ fluxes in a Mediterranean Bay dominated by seagrass beds (Palma Bay, NW Mediterranean). Biogeosciences Discussions 1:755-802. 
Hansen, H. P. And F. KorolefF. 1999. Determination of nutrients, p. 170-174. In K. Grasshoff, K. Kremling, and M. Ehrhardt (eds.), Methods of Seawater Analysis, 3rd edition. Verlag Chemie, Weinheim, Germany.

Hansen, J. W., B. Thamdrup, and B. B. Jørgensen. 2000. Anoxic incubation of sediment in gas-tight plastic bags: A method for biogeochemical process studies. Marine Ecology Progress Series 208:273-282

HemmingA, M. And C. M. Duarte. 2000. Seagrass Ecology, 1st edition. Cambridge University Press, Cambridge, Massachusetts.

Holmer, M., C. M. Duarte, H. T. S. Boschker, and C. Barrón. 2004. Carbon cycling and bacterial carbon sources in pristine and impacted Mediterranean seagrass sediments. Aquatic Microbial Ecology 36:227-237.

Holmer, M., C. M. Duarte, And N. Marba. 2003. Sulfur cycling and seagrass (Posidonia oceanica) status in carbonate sediments. Biogeochemistry 66:223-239.

HuetTel, M. AND G. GuST. 1992. Solute release mechanisms from confined sediment cores in stirred benthic chambers and flume flows. Marine Ecology Progress Series 82:187-197.

KIRK, J. T. O. 1983. Light and Photosynthesis in Aquatic Ecosystems, 1st edition. Cambridge University Press, Cambridge, Massachusetts.

Ku, T. C. W., L. M. Walter, M. L. Coleman, R. E. Blake, and A. M. MARTINI. 1999. Coupling between sulfur recycling and syndepositional carbonate dissolution: Evidence from oxygen and sulfur isotope composition of pore water sulfate, south Florida platform, U.S.A. Geochimica et Cosmochimica Acta 63:2529-2546.

Lepoint, G., S. Havelange, S. Gobert, and J. M. Bouquegneau. 1999. Fauna vs flora contribution to the leaf epiphytes biomass in a Posidonia oceanica seagrass bed (Revellata Bay, Corsica). Hydrobiologia 394:63-67.

López, N. I., C. M. Duarte, F. Vallespinós, J. Romero, and T. Alcoverro. 1995. Bacterial activity in NW Mediterranean seagrass (Posidonia oceanica) sediments. Journal of Experimental Marine Biology and Ecology 187:39-49.

Mateo, M. A., J. Romero, M. Pérez, M. M. Littler, and D. S. LITTLER. 1997. Dynamics of millenary organic deposits resulting from the growth of the Mediterranean seagrass Posidonia oceanica. Estuarine and Coastal Shelf Science 44:103-110.

Mateo, M. Á., J.-L. SÁnchez-LizAso, And J. Romero. 2003. Posidonia oceanica "banquettes": A preliminary assessment of the relevance for meadow carbon and nutrient budget Estuarine and Coastal Marine Science 56:85-90.
McGlathery, K., R. MARINO, AND R. W. Howarth. 1994. Variable rates of phosphate uptake by shallow marine carbonate sediments: Mechanisms and ecological significance. Biogeochemistry 25:127-146.

Middelburg, J. J., C. M. Duarte, and J.-P. Gattuso. 2005. Respiration in coastal benthic communities, p. 206-224. In P. A. del Giorgio and P. J. LeB. Williams (eds.), Respiration in Aquatic Ecosystems. Oxford University Press, Oxford, U.K..

Modigh, M., M. Lorenti, And L. Mazzella. 1998. Carbon assimilation in Posidonia oceanica: Biotic determinants. Botanica Marina 41:249-256.

Morse, J. W., J. J. Zullig, R. L. Iverson, G. R. Chopin, A. Mucci, AND F. J. Millero. 1987. The influence of seagrass bed on carbonate sediments in the Bahamas. Marine Chemistry 22:7183.

Nelsen, JR., J. E. AND R. N. GinsBurg. 1986. Calcium carbonate production by epibionts on Thalassia in Florida Bay. Journal of Sedimentary Petrology 56:622-628.

Ogrinc, N., J. Faganeli, AND J. Pezdic. 2003. Determination of organic carbon remineralization in near-shore marine sediments (Gulf of Trieste, Northern Adriatic) using stable carbon isotopes. Organic Geochemistry 34:681-692.

Romero, J. 1988. Epifitos de las hojas de Posidonia oceanica: Variaciones estacionales y batimetricas de biomasa en la pradera de las islas Medes (Girona). Oecologica Aquatica 9:19-25.

Roy, R., L. Roy, J. C. Vogel, C. Porter-Moore, T. Pearson, C. E. Good, F. J. Millero, and D. M. Campbell. 1993. The dissociation constants of carbonic acid in seawater at salinities 5 to 45 and temperatures 0 to $45^{\circ} \mathrm{C}$. Marine Chemistry 44:249267.

Smith, S. V. AND G. S. Key. 1975. Carbon dioxide and metabolism in marine environments. Limnology and Oceanography 20:493495.

YATES, K. K. AND R. B. HALlEy. 2003. Measuring coral reef community metabolism using new benthic chamber technology. Coral Reefs 22:247-255.

YATES, K. K. AND R. B. HALley. 2006. Diurnal variation in rates of calcification and carbonate sediment dissolution in Florida Bay. Estuaries and Coasts 29:24-39.

Ziegler, S. AND R. BenNer. 1998. Ecosystem metabolism in a subtropical, seagrass-dominated lagoon. Marine Ecology Progress Series 173:1-12.

Received, September 29, 2005 Accepted, February 11, 2006 